\title{
Osteodifferentiation of Human Preadipocytes Induced by Strontium Released from Hydrogels
}

\author{
Valeria Nardone, Sergio Fabbri, Francesca Marini, Roberto Zonefrati, \\ Gianna Galli, Annamaria Carossino, Annalisa Tanini, and Maria Luisa Brandi
}

Department of Internal Medicine, University of Florence, 50139 Florence, Italy

Correspondence should be addressed to Maria Luisa Brandi, m.brandi@dmi.unifi.it

Received 29 April 2012; Accepted 21 June 2012

Academic Editor: Giovanni Vozzi

Copyright ( $) 2012$ Valeria Nardone et al. This is an open access article distributed under the Creative Commons Attribution License, which permits unrestricted use, distribution, and reproduction in any medium, provided the original work is properly cited.

In recent years, there has been an increasing interest in interactive application principles of biology and engineering for the development of valid biological systems for tissue regeneration, such as for the treatment of bone fractures or skeletal defects. The application of stem cells together with biomaterials releasing bioactive factors promotes the formation of bone tissue by inducing proliferation and/or cell differentiation. In this study, we used a clonal cell line from human adipose tissue-derived mesenchymal stem cells (hADSCs or preadipocytes), named PA2-E12, to evaluate the effects of strontium $\left(\mathrm{Sr}^{2+}\right)$ released in the culture medium from an amidated carboxymethylcellulose (CMCA) hydrogel enriched with different $\mathrm{Sr}^{2+}$ concentrations on osteodifferentiation. The osteoinductive effect was evaluated through both the expression of alkaline phophatase (ALP) activity and the hydroxyapatite (HA) production during 42 days of induction. Present data have shown that $\mathrm{Sr}^{2+}$ released from $\mathrm{CMCA}$ promotes the osteodifferentiation induced by an osteogenic medium as shown by the increase of ALP activity at 7 and 14 days and of HA production at 14 days. In conclusion, the use of biomaterials able to release in situ osteoinductive agents, like $\mathrm{Sr}^{2+}$, could represent a new strategy for future applications in bone tissue engineering.

\section{Introduction}

The repair of large bone defects, due to trauma, tumors, and/or congenital malformations is a global health problem and a major challenge for orthopaedic surgery [14]. Current treatment options include surgical reconstruction by organ/tissue transplantation of autografts/allografts. These traditional methods are often associated with limited availability in autografts, and risk of immunogenicity, infection, and local pain $[5,6]$. Today, tissue engineering by artificial tissue grafts represents a valid alternative for overcoming the therapeutic and methodological limitations of current therapy [7-11]. The aim of tissue engineering is to produce functional tissues in vitro [1], in order to improve in vivo regeneration using cells, biodegradable biomaterials/scaffolds, and bioactive factors [10, 12-16]. The advantage of this approach is that it can reduce the number of surgical operations and the time of recovery for solving the clinical problems.
Scaffolds are key components acting as a mold for interaction with the cells, also providing support for cell adhesion, growth, and differentiation. A good scaffold has to be osteoconductive (to induce the cells to adhere, migrate, and proliferate), osteoinductive (to be able to induce proliferation of undifferentiated cells and their subsequent differentiation into osteoblasts), biocompatible, and biodegradable [17]. Moreover, a scaffold must possess mechanical properties similar to the native tissue to be repaired. A further requirement for a scaffold, particularly in bone engineering, is a controllable interconnected porosity to promote engraftment, proliferation, and migration of bone cells, as well as synthesis of the extracellular matrix (ECM), vascularization of the ingrown tissue, and interconnection between the implant and the bone tissue, in order to ensure mechanical stability $[14,18,19]$. In addition, the mechanical properties of the scaffold must be sufficient and not collapse during handling and during the patient's normal activities. 
Finally, the scaffold must be easily sterilizable to prevent infections [20].

The other component for the engineering of a viable tissue construct is the use of cell therapy. Mesenchymal stem cells (MSCs), given their osteoblast-driven differentiation potential, represent the most suitable cell source in bone regeneration therapies. MSCs are multipotent cells identified in numerous tissues such as bone marrow, fat, placenta, umbilical cord, human amniotic fluid, dental pulp, and skeletal muscle [21-28]. Many studies have demonstrated the usefulness of MSCs for regenerative medicine, in particular in osteoarticular disorders [29]. MSCs, isolated from adult bone marrow (BMMSCs), can be induced in vitro and in vivo to differentiate into various mesenchymal lineages (bone, cartilage, tendon, adipose tissue, and muscle). These cells can also differentiate into nonmesenchymal cell lines, such as endothelial cells [30], cardiac myoblasts [31], neuronal cells [32], and hepatocytes [33]. BMMSCs have been demonstrated to stimulate bone formation in skeletal defects and nonunion, through cytokines and growth factors secreted by the transplanted cells $[34,35]$. Recent studies have demonstrated that also human adipose tissue-derived mesenchymal stem cells (hADSCs) are able to differentiate into active osteoblasts, like their bone marrow counterpart (hBMMSCs) [36-38]. These characteristics, together with the greater quantity obtainable and the low invasiveness of fat sampling procedure, make adipose tissue an excellent cell source for bone regeneration [38].

Several studies have investigated the applicability of hydrogels, water-soluble polymers which swell to form a gel-like substance upon exposure to water $[39,40]$, acting as biodegradable and biocompatible scaffolds for bone grafts and cartilage regeneration [41-48]. In vitro studies have demonstrated that amidated carboxymethyl cellulose (CMCA) hydrogel is a potential filler for cartilage defects. Normal human articular chondrocytes seeded on CMCA [48] promote synthesis of ECM components, significantly increasing production of both type II collagen and aggregan, the hallmark proteoglycan for hyaline cartilage [49]. These data suggest that CMCA hydrogels could represent a good support for tissue engineering in osteoarticular disorders [48]. Currently, attention has been focused on the use of scaffolds enriched with bioactive factors such as biologically active proteins, growth factors, hormones, cytokines, and drugs capable of inducing cell proliferation and/or differentiation [50-54]. Moreover, the addition of anti-inflammatory drugs and antibiotics can make the prevention of infections after surgery possible [55].

An agent registered as an antifracture drug is strontium ranelate (SR), whose active component on bone remodelling is the $\mathrm{Sr}^{2+}$ ion [56-58]. Unlike all the other treatments for osteoporosis, SR has a dual effect on bone remodelling, being able, simultaneously, to stimulate osteoblast-mediated bone formation and to inhibit osteoclast-induced bone resorption [59]. Indeed, SR stimulates in vitro osteoblastic differentiation markers such as alkaline phosphatase (ALP), bone sialoprotein, and osteocalcin (OCN) and also inhibits the proliferation of osteoclast precursors as well as osteoclastogenesis $[60,61]$.
In vitro studies have shown that the use of biomaterials enriched with $\mathrm{Sr}^{2+}$ is promising. In fact, strontium-dopedcalcium-polyphosphate-(SCPP) based bioceramic scaffolds combined with the rat osteosarcoma cell line ROS17/2,8 promoted cell proliferation and induced mRNA expression and release of two angiogenic factors, vascular endothelial growth factor (VEGF) and basic fibroblast growth factor (bFGF) [62-64].

The encouraging results obtained by the use of cells combined with hydrogels and by the use of scaffolds enriched with $\mathrm{Sr}^{2+}$ on the in vitro osteogenic differentiation of hADSCs, prompted us to perform a study on the combined use of hydrogels and $\mathrm{Sr}^{2+}$, to assess its potential for future applications in bone tissue engineering.

\section{Materials and Methods}

2.1. CMCA Hydrogel and CMCA Hydrogel Enriched with $\mathrm{Sr}^{2+}$ Preparation. The CMCA hydrogel and CMCA hydrogel enriched with $\mathrm{Sr}^{2+}$ used in this study were obtained from BioSuMa (Lima Corporate S.p.a., Villanova di San Daniele del Friuli, Italy). The procedure for the realization of amidic derivative of CMC-based hydrogel (CMCA) was previously reported [65]. The kinetics of degradation in vitro of CMCA hydrogel were evaluated at 7 days by hyialuronidase and $\beta$-mannosidase enzymes with percentages of degradation, respectively, of $7 \%$ and $32 \%$ [experimental data not shown, provided by R. Barbucci (C.R.I.S.M.A) University of Siena]. The preparation of CMCA enriched with $\mathrm{Sr}^{2+}$ was carried out by bulge of gel in aqueous solutions of 3, 30, $300 \mu \mathrm{M}$ and $3 \mathrm{mM} \mathrm{SrCl}_{2}$, exploiting the property of hydrogel to incorporate a large quantity of water. The hydrogel enriched with $\mathrm{Sr}^{2+}$ was stratified in transwell 6-well Millicell inserts (Millipore) with $2.5 \mathrm{~cm}$ diameter, dehydrated, and sterilized by ethylene oxide. The evaluation of the amount of $\mathrm{Sr}^{2+}$ incorporated in the hydrogel and then released into the medium was carried out by inductively coupled plasma mass spectrometry (ICPMS) technique that uses an ICP torch to produce the ionization, and a mass spectrometer to separate and detect the ions produced [66].

2.2. Cell Culture. A primary cell line of hADSCs, named PA2, previously cultured and characterized for its multipotency in our laboratory [39], was plated on tissue culture polystyrene (tPS) substrate at $37^{\circ} \mathrm{C}$ in humidified atmosphere with $5 \% \mathrm{CO}_{2}$ in growth medium (GM) [Ham's F12 Coon's modification medium supplemented with $10 \%$ fetal calf serum (FCS), $100 \mathrm{IU} / \mathrm{mL}$ penicillin, $100 \mu \mathrm{g} / \mathrm{mL}$ streptomycin, and $1 \mathrm{ng} / \mathrm{mL}$ basic fibroblast growth factor (bFGF)]. The medium was refreshed twice a week and cells were used for further subculturing or cryopreservation upon reaching $5 \times 10^{3}$ cells $/ \mathrm{cm}^{2}$.

2.3. Cell Cloning. The primary cell line $\mathrm{PA} 2$ at the $3 \mathrm{rd}$ passage were used for cell cloning. Cells in active phase of growth were cloned by the dilution plating technique. Cells were detached with trypsin $1: 2500.4 \mathrm{mg} / \mathrm{mL}$ in Dulbecco's phosphate-buffered saline (DPBS) without $\mathrm{Ca}^{2+}$ without 
$\mathrm{Mg}^{2+}$ with EDTA $0.2 \mathrm{mg} / \mathrm{mL}$ and with glucose $1 \mathrm{mg} / \mathrm{mL}$, resuspended in Coon's medium $+20 \%$ FCS. The cell suspension was diluted to a concentration of 10 cells $/ \mathrm{mL}$ in the following cloning medium: Coon's medium $+20 \%$ FCS supplemented with $25 \%$ conditioned medium prepared from human fetal fibroblast culture. The cell suspension was maintained in agitation and $0.1 \mathrm{~mL}$ was rapidly distributed per well of a 96-multiwell plate. Each well was carefully observed and the wells containing only one cell were scored. The cloning culture was incubated at $37^{\circ} \mathrm{C}$ in humidified air with $5 \% \mathrm{CO}_{2}$. When colonies reached the consistency of 500600 cells, they were detached, collected, and first transferred in 24-multiwell plates and subsequently expanded in $60 \mathrm{~mm}$ and $100 \mathrm{~mm}$ dishes. Seven finite clonal lines, named PA2-C5, PA2-D4, PA2-E12, PA2-F2, and PA2-H8, were obtained from the PA2 cell line. PA2-E12 was chosen among these finite clonal cell lines for its high proliferative capacity.

2.4. Clonal Cell Line Characterization. The characterization of PA2-E12 finite clonal cell line, to verify its multi-potency, was performed by studying the adipogenic and osteogenic differentiation, as previously described [38].

2.5. Adhesion and Morphology Analysis. CMCA hydrogel was sterilized by ethanol, balanced in GM, and afterwards distributed on tPS. The plates coated with CMCA hydrogel were preincubated at $37^{\circ} \mathrm{C}$ in humidified atmosphere with $5 \% \mathrm{CO}_{2}$ in GM for $4 \mathrm{~h}$. Thereafter, PA2-E12 cells were cultured in GM and seeded on CMCA hydrogel. PA2-E12 cells cultured on CMCA hydrogel were evaluated for cell morphology and capacity to adhere to CMCA hydrogel after $1,3,6,9,12$, and 15 days from seeding. Total cellular RNA was isolated both from cells cultured in GM on tPS and cells cultured in GM on CMCA hydrogel during time of culture.

2.6. Osteogenic Differentiation in Presence of CMCA Hydrogel Enriched with $\mathrm{Sr}^{2+}$. PA2-E12 cells were previously seeded at semiconfluence on tPS in 6-multiwell plates at a cell density of $1 \times 10^{4}$ cells $/ \mathrm{cm}^{2}$ in GM. After 3 days at achievement of confluence, the cells were differentiated by on osteogenic medium (OM): Coon's medium supplemented with $10 \%$ FCS, $100 \mathrm{IU} / \mathrm{mL}$ penicillin, $100 \mu \mathrm{g} / \mathrm{mL}$ streptomycin, $10 \mathrm{nM}$ dexamethasone, $10 \mathrm{mM} \beta$-glycerophosphate, and $200 \mathrm{mM}$ sodium L-ascorbyl-2-phosphate. The osteogenic differentiation was carried out in OM in the presence of $3 \mu \mathrm{M}-3 \mathrm{mM}$ $\mathrm{Sr}^{2+}$. In parallel, experiments in OM were carried out in the presence of transwell containing CMCA hydrogel enriched with $0,3,30,300 \mu \mathrm{M}$ and $3 \mathrm{mM} \mathrm{Sr}^{2+}$. The medium was refreshed twice a week. The expression of the osteoblastic phenotype was evaluated quantitatively by ALP activity and by hydroxyapatite (HA) production at different times from 1 to 42 days of culture and respective values were normalized by DNA content/well. For ALP assay, each well was incubated with $500 \mu \mathrm{L}$ of 4 -methylumbelliferyl phosphate in $280 \mathrm{mM}$ Tris- $\mathrm{HCl}$ buffer $\mathrm{pH} 9.0$ for $15 \mathrm{~min}$ at $37^{\circ} \mathrm{C}$. The reaction was stopped by the addition of $2 \mathrm{~mL}$ of $0.1 \mathrm{M} \mathrm{NaOH}$. ALP activity was measured with a spectrofluorometer LS55 (PerkinElmer) at $365 \mathrm{~nm} \lambda$ excitation and $445 \mathrm{~nm} \lambda$ emission and expressed in $\mu \mathrm{U}$ ALP/ng DNA using a standard curve of 4-methylumbelliferone $50 \mathrm{nM}-10 \mu \mathrm{M}$ in $280 \mathrm{mM}$ Tris$\mathrm{HCl}$ buffer $\mathrm{pH}$ 9.0. For HA assay, cells were grown in $\mathrm{OM}$ containing $1 \mathrm{mg} / \mathrm{mL}$ calcein, fixed and washed. Afterwards, each well was incubated with $2 \mathrm{~mL}$ of $50 \mathrm{mM}$ NaEDTA for $30 \mathrm{~min}$ at $37^{\circ} \mathrm{C}$, then the fluorescence was measured with spectrofluorometer LS55 (PerkinElmer) at $494 \mathrm{~nm} \lambda$ excitation and $517 \mathrm{~nm} \lambda$ emission and expressed in $\mu \mathrm{g} \mathrm{HA} / \mathrm{ng}$ DNA using a standard curve of HA $25 \mathrm{ng} / \mathrm{mL}-500 \mu \mathrm{g} / \mathrm{mL}$ solubilized in $50 \mathrm{mM}$ NaEDTA. A cytochemical evaluation for ALP was carried out at 14 days of culture using a method of simultaneous coupling between naphthol and diazonium salt to obtain an azoic dye. The cells were washed with DPBS (two times), stained with a specific dye mixture $(5 \mathrm{mg}$ Naphthol-AS-MX phosphate sodium salt dissolved in $1 \mathrm{~mL}$ dimethyl sulfoxide), $40 \mathrm{mg}$ fast red violet $\mathrm{LB}$ dissolved in $49 \mathrm{~mL}$ Tris- $\mathrm{HCl}$ buffer $280 \mathrm{mM} \mathrm{pH} 9.0$ for $30 \mathrm{~min}$ at $37^{\circ} \mathrm{C}$. Then, the cells were washed with DPBS (two times, fixed in $4 \%$ paraformaldehyde (PFA)/DPBS for $15 \mathrm{~min}$ and washed with ultrapure water three times). ALP+ cells were stained in red. No staining was carried out to highlight HA deposits that result in black because of their optical density property in transmitted light.

2.7. Statistical Analysis. The statistical significance of differences between mean values of ALP activity and of HA deposits production between controls and stimuli were evaluated by two-tailed Student's $t$-test on experiments repeated three times and carried out in quadruplicate.

\section{Results}

3.1. Adhesion and Cellular Morphology. PA2-E12 cultured in GM on tPS (controls) showed an optimal adhesion to the surface with a fusiform shape after 1 day of culture (Figure 1(a)). PA2-E12 cultured on CMCA hydrogels showed a round morphology and a limited adhesion on CMCA hydrogels after 1 day of culture (Figure 1(b)). Total RNA of cells cultured in GM on tPS increased during time of culture (1-15 days) with cellular proliferation and the cells maintained a fusiform shape. Total RNA of cells adherent to hydrogel was constant during time of culture (1-15 days), but it was near to the lower limit detectable due to low number of cells adherent to hydrogel.

3.2. $\mathrm{Sr}^{2+}$ Loading on CMCA Hydrogel and $\mathrm{Sr}^{2+}$ Release and Accumulation in the Culture Medium. The percentage of $\mathrm{Sr}^{2+}$ incorporation in the CMCA hydrogel was $95 \%$ of the total exposure and the $\mathrm{Sr}^{2+}$ released in the culture medium at $37^{\circ} \mathrm{C}$ for each hour resulted to be of the order of $2 \%$ the ion incorporated into the hydrogel. The $\mathrm{Sr}^{2+}$ was accumulated in the culture medium until the replacement of the old medium with fresh medium (Table 1). During time of culture of cells, CMCA hydrogel showed no alteration or degradation signs in the structure 3D by microscopic observation.

\subsection{Effects of $\mathrm{Sr}^{2+}$ Dissolved Directly in $\mathrm{OM}$ and of $\mathrm{Sr}^{2+}$ Released from CMCA Hydrogel in OM on ALP Activity.}


TABLE 1: Release and accumulation of $\mathrm{Sr}^{2+}$ in the culture medium from transwells with CMCA enriched with $\mathrm{Sr}^{2+}$.

\begin{tabular}{|c|c|c|c|c|c|}
\hline $\begin{array}{l}\text { Days of } \\
\text { culture }\end{array}$ & $\begin{array}{l}{\left[\mathrm{Sr}^{2+}\right] \text { accumulated in }} \\
\text { the culture medium in } \\
\text { presence of CMCA } \\
\text { enriched with } 3 \mathrm{mM} \mathrm{Sr}^{2+}\end{array}$ & $\begin{array}{l}{\left[\mathrm{Sr}^{2+}\right] \text { accumulated in the }} \\
\text { culture medium in } \\
\text { presence of CMCA } \\
\text { enriched with } 300 \mu \mathrm{M} \mathrm{Sr}^{2+}\end{array}$ & $\begin{array}{l}{\left[\mathrm{Sr}^{2+}\right] \text { accumulated in the }} \\
\text { culture medium in } \\
\text { presence of CMCA } \\
\text { enriched with } 30 \mu \mathrm{M} \mathrm{Sr}^{2+}\end{array}$ & $\begin{array}{l}{\left[\mathrm{Sr}^{2+}\right] \text { accumulated in }} \\
\text { the culture medium in } \\
\text { presence of CMCA } \\
\text { enriched with } 3 \mu \mathrm{M} \mathrm{Sr}{ }^{2+}\end{array}$ & $\begin{array}{l}\text { Replacement of the } \\
\text { old OM with fresh } \\
\text { OM }\end{array}$ \\
\hline 1 & $1095 \pm 33 \mathrm{mM}$ & $110 \pm 3 \mu \mathrm{M}$ & $12 \pm 0.4 \mu \mathrm{M}$ & $<3 \mu \mathrm{M}$ & \\
\hline 2 & $1769 \pm 68 \mathrm{mM}$ & $172 \pm 5 \mu \mathrm{M}$ & $19 \pm 0.5 \mu \mathrm{M}$ & $<3 \mu \mathrm{M}$ & \\
\hline 3 & $2185 \pm 76 \mathrm{mM}$ & $220 \pm 6 \mu \mathrm{M}$ & $20 \pm 0.5 \mu \mathrm{M}$ & $<3 \mu \mathrm{M}$ & $\mathrm{X}$ \\
\hline 4 & $256 \pm 8 \mu \mathrm{M}$ & $24 \pm 0.7 \mu \mathrm{M}$ & $2.6 \pm 0.1 \mu \mathrm{M}$ & $<3 \mu \mathrm{M}$ & \\
\hline 5 & $413 \pm 8 \mu \mathrm{M}$ & $43 \pm 1.1 \mu \mathrm{M}$ & $4.2 \pm 0.1 \mu \mathrm{M}$ & $<3 \mu \mathrm{M}$ & \\
\hline 6 & $510 \pm 14 \mu \mathrm{M}$ & $50 \pm 1.6 \mu \mathrm{M}$ & $5.1 \pm 0.2 \mu \mathrm{M}$ & $<3 \mu \mathrm{M}$ & \\
\hline 7 & $570 \pm 16 \mu \mathrm{M}$ & $59 \pm 1.5 \mu \mathrm{M}$ & $6.0 \pm 0.2 \mu \mathrm{M}$ & $<3 \mu \mathrm{M}$ & $\mathbf{X}$ \\
\hline 8 & $37 \pm 1 \mu \mathrm{M}$ & $3.6 \pm 0.1 \mu \mathrm{M}$ & $<3 \mu \mathrm{M}$ & $<3 \mu \mathrm{M}$ & \\
\hline 9 & $59 \pm 2 \mu \mathrm{M}$ & $6.0 \pm 0.2 \mu \mathrm{M}$ & $<3 \mu \mathrm{M}$ & $<3 \mu \mathrm{M}$ & \\
\hline 10 & $73 \pm 2 \mu \mathrm{M}$ & $7.2 \pm 0.2 \mu \mathrm{M}$ & $<3 \mu \mathrm{M}$ & $<3 \mu \mathrm{M}$ & $\mathrm{X}$ \\
\hline 11 & $9 \pm 0.3 \mu \mathrm{M}$ & $<3 \mu \mathrm{M}$ & $<3 \mu \mathrm{M}$ & $<3 \mu \mathrm{M}$ & \\
\hline 12 & $14 \pm 0.4 \mu \mathrm{M}$ & $<3 \mu \mathrm{M}$ & $<3 \mu \mathrm{M}$ & $<3 \mu \mathrm{M}$ & \\
\hline 13 & $17 \pm 0.6 \mu \mathrm{M}$ & $<3 \mu \mathrm{M}$ & $<3 \mu \mathrm{M}$ & $<3 \mu \mathrm{M}$ & \\
\hline 14 & $19 \pm 0.6 \mu \mathrm{M}$ & $<3 \mu \mathrm{M}$ & $<3 \mu \mathrm{M}$ & $<3 \mu \mathrm{M}$ & $\mathrm{X}$ \\
\hline 17 & $<3 \mu \mathrm{M}$ & $<3 \mu \mathrm{M}$ & $<3 \mu \mathrm{M}$ & $<3 \mu \mathrm{M}$ & $\mathrm{X}$ \\
\hline 21 & $<3 \mu \mathrm{M}$ & $<3 \mu \mathrm{M}$ & $<3 \mu \mathrm{M}$ & $<3 \mu \mathrm{M}$ & $\mathrm{X}$ \\
\hline 28 & $<3 \mu \mathrm{M}$ & $<3 \mu \mathrm{M}$ & $<3 \mu \mathrm{M}$ & $<3 \mu \mathrm{M}$ & $\mathrm{X}$ \\
\hline 42 & $<3 \mu \mathrm{M}$ & $<3 \mu \mathrm{M}$ & $<3 \mu \mathrm{M}$ & $<3 \mu \mathrm{M}$ & $\mathrm{X}$ \\
\hline
\end{tabular}

Values expressed as means $\pm \mathrm{SD}$ of $\mathrm{Sr}^{2+}$ at times for quantitative ALP and HA analysis are indicated in bold.

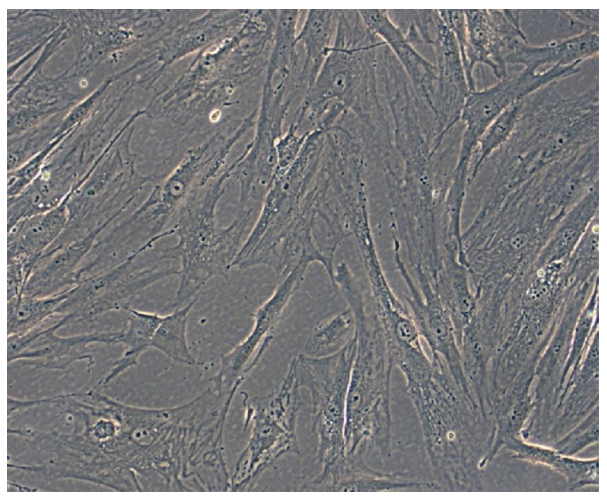

(a)

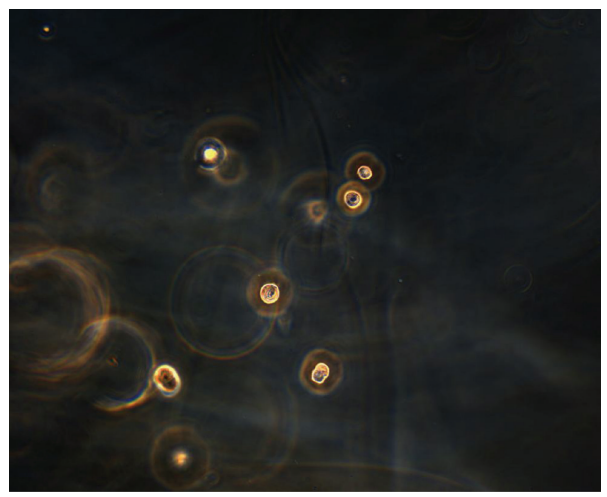

(b)

Figure 1: (a) Phase-contrast microscopy (20x objective) of PA2-E12 cultured in GM on tPS after 1 day of culture. (b) Phase-contrast microscopy (20x objective) of PA2-E12 on CMCA hydrogels after 1 day of culture.

An increasing ALP activity was measured from 1 to 14 days in all samples with a decreasing trend afterwards. The production of ALP was always present in all samples after 42 days with mean increases of $282 \%$ compared to 1 day of induction. Significant increases of ALP activity versus controls were observed in cells cultured in OM in presence of $\mathrm{Sr}^{2+}$ released from CMCA hydrogel enriched with $3 \mathrm{mM} \mathrm{Sr}^{2+}$ (corresponding to culture medium concentrations of $600 \mu \mathrm{M}$ after 7 days of culture, $20 \mu \mathrm{M}$ after 14 days, and $20 \mathrm{nM}$ after 28 days) with maximum percent increase of $99 \%$ after 14 days (Figure 2). Conversely, in CMCA hydrogel enriched with $0,3,30$ and $300 \mu \mathrm{M} \mathrm{Sr}^{2+}$, no effect was observed on ALP induction (Figure 2).

Similarly, in cells cultured in OM containing $300 \mu \mathrm{M}$ and $3 \mathrm{mM} \mathrm{Sr}^{2+}$, significant increases compared to controls were observed after 7 and 14 days (maximal increases after 14 days for $300 \mu \mathrm{M}$ and $3 \mathrm{mM} \mathrm{Sr}^{2+}$, resp., $85 \%$ and $106 \%$ ), with a prolonged effect up to 28 days only in the presence of $3 \mathrm{mM}$ $\mathrm{Sr}^{2+}$. As expected, significant increases of ALP activity were not observed in cells cultured in OM containing 3 or $30 \mu \mathrm{M}$ 


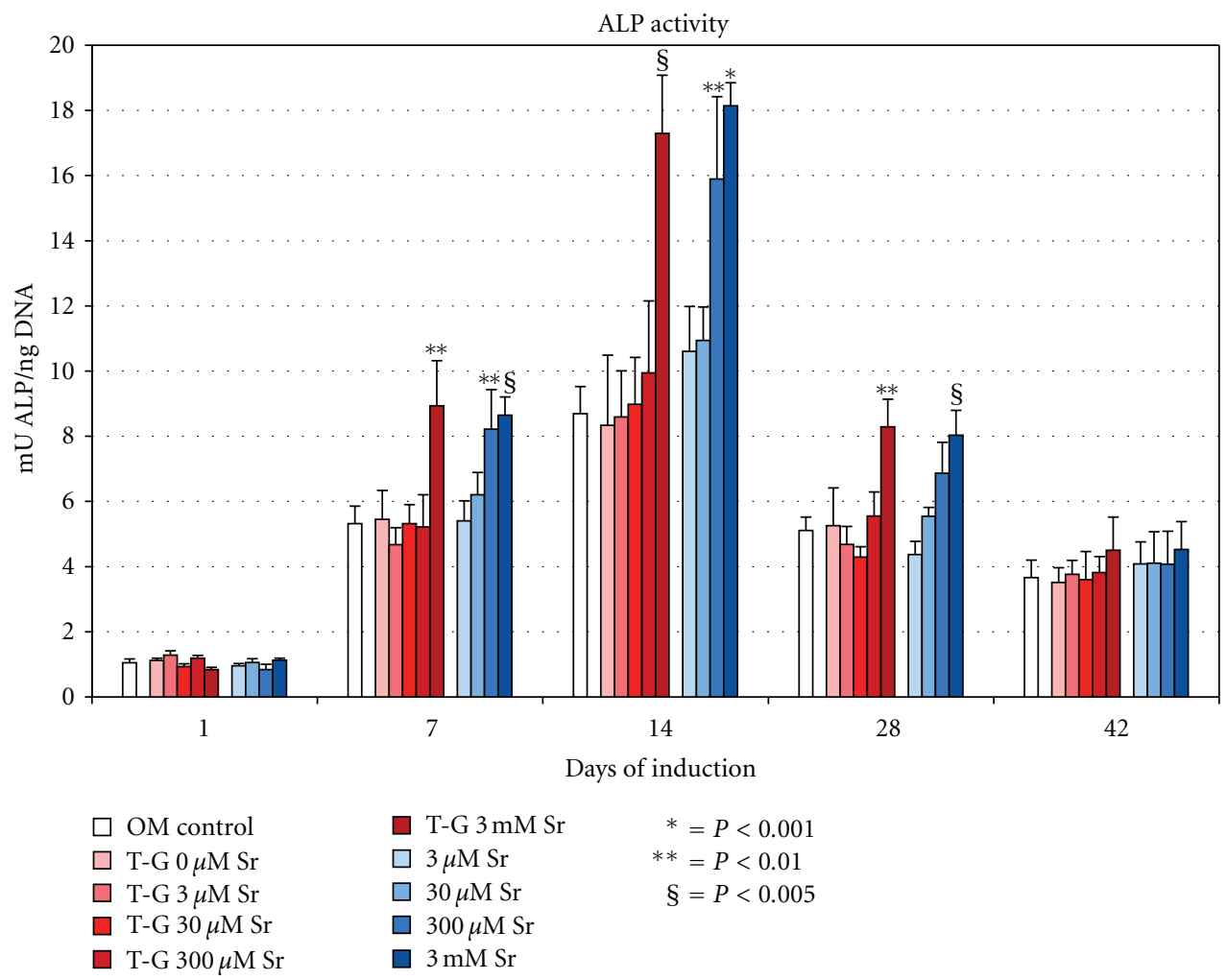

FIGURE 2: Quantitative analysis of ALP enzymic activity in PA2-E12 cultured on tPS from 1 to 42 days in OM in the presence of transwell containing CMCA hydrogel (T-G) enriched with scalar concentrations of strontium (T-G $0,3,30,300 \mu \mathrm{M}$ and $3 \mathrm{mM} \mathrm{Sr^{2+ }}$ ) or in OM only containing scalar concentrations of strontium $\left(3,30,300 \mu \mathrm{M}\right.$ and $\left.3 \mathrm{mM} \mathrm{Sr}^{2+}\right)$. The control is represented by cells cultured in $\mathrm{OM}$ without $\mathrm{Sr}^{2+}$.

$\mathrm{Sr}^{2+}$. After 42 days of induction, ALP activity decreased in all samples, without significant differences compared to controls (Figure 2).

\subsection{Effects of $\mathrm{Sr}^{2+}$ Dissolved Directly in $\mathrm{OM}$ and of $\mathrm{Sr}^{2+}$} Released from CMCA Hydrogel in OM on the Formation HA Deposits. The formation of HA deposits begins to be observed after 14 days, increasing during time up to 42 days of culture. Low concentrations of $\mathrm{Sr}^{2}$ directly dissolved in OM did not modify the progression of HA deposition, while at $300 \mu \mathrm{M}$ and $3 \mathrm{mM} \mathrm{Sr}^{+2}$ the accumulation of HA was dramatically reduced at all analyzed times. Conversely, for cells cultured with $30 \mu \mathrm{M} \mathrm{Sr}^{2+}$ directly dissolved in OM, significant increases of HA deposits compared to control were observed only after 14 days with percent increase of $+98 \%$. Similarly, at 14 days, significant increases of HA deposits formation were observed for cells cultured in OM in the presence of $\mathrm{Sr}^{2+}$ released from the CMCA hydrogel enriched with $3 \mathrm{mM} \mathrm{Sr}{ }^{+2}$ and accumulated in the culture medium at a final concentration of $20 \mu \mathrm{M} \mathrm{Sr}^{+2}$ (Table 1) with percent increase: $169 \%$ versus control. After 28 and 42 days, no significant differences compared to control were observed for cells cultured with $\mathrm{Sr}^{2+}$-enriched CMCA hydrogel (Figure 3).

3.5. ALP and HA Activity. According to the results obtained with the quantitative ALP and HA analysis, $3 \mathrm{mM} \mathrm{Sr}{ }^{2+}$ concentration loaded on CMCA hydrogel and $30 \mu \mathrm{M} \mathrm{Sr}{ }^{2+}$ concentration directly added to OM were used for light microscopy observation. A similar qualitative osteogenic differentiation was observed at 14 days in cells cultured on tPS in OM in the presence of $3 \mathrm{mM} \mathrm{Sr}^{2+}$-enriched CMCA hydrogel, in the presence of $30 \mu \mathrm{M} \mathrm{Sr}^{2+}$ added directly to the $\mathrm{OM}$, and in the presence of control OM alone (Figure 4). In all the three conditions an initial formation of HA deposits was observed with a higher density in the presence of $\mathrm{Sr}^{2+}$ ion, with cell groups at different staining intensity for ALP activity being present in all conditions, but more abundant in the presence of the $\mathrm{Sr}^{2+}$ ion(Figure 4).

\section{Discussion}

The interaction between stem cells and biomaterials represents an innovation in the tissue-engineered field for the replacement of damaged bone tissues, representing a great challenge for orthopaedic surgeons in the repair of bone and/or cartilage large defects. To offer the best opportunities for bone tissue repair innovation, the development of both novel biomaterials and ideal cell models is needed.

The design of biomimetic materials for the development of biomaterials is an area of great interest for tissue engineering applications [67-69]. Biomaterials can be coated with bioactive molecules that can serve as an artificial extracellular matrix (ECM) providing suitable background to promote 


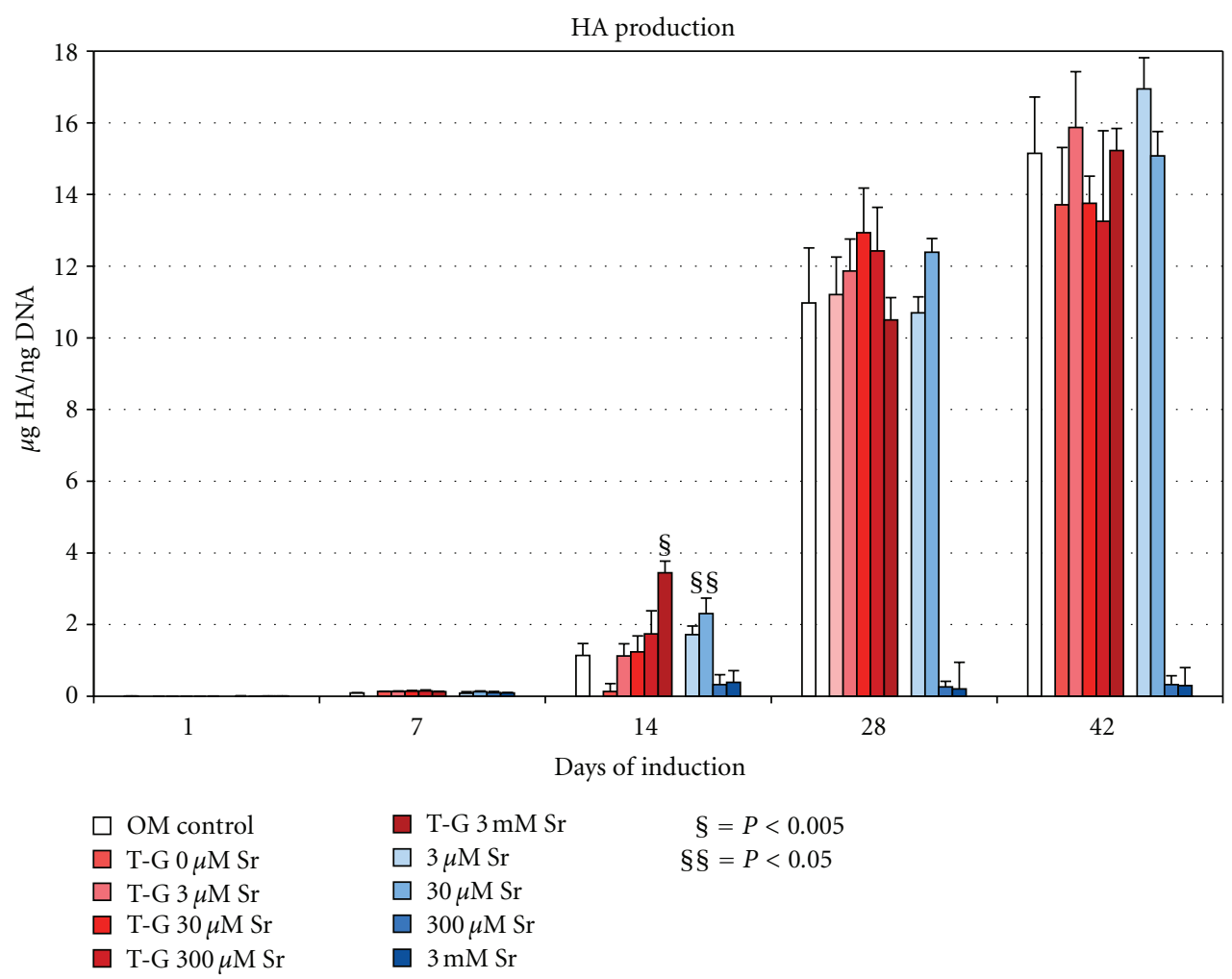

FIGURE 3: Quantitative analysis of the formation of HA deposits in PA2-E12 cultured on tPS from 1 to 42 days in OM in presence of transwell

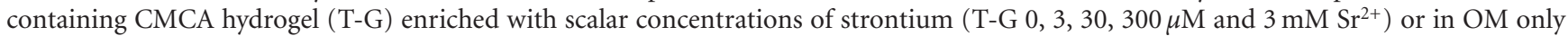
containing scalar concentrations of strontium $\left(3,30,300 \mu \mathrm{M}\right.$ and $\left.3 \mathrm{mM} \mathrm{Sr}^{2+}\right)$. The control is represented by cells cultured in OM without $\mathrm{Sr}^{2+}$.

cell adhesion and proliferation [70]. The surface modification of biomaterials, coated with bioactive molecules, can be made using long chains of ECM proteins such as fibronectin (FN) and laminin (LN), or a short peptide such as Arg-GlyAsp (RGD) derived from FN and LN [53]. Hydrogels are able to protect drugs, peptides, and especially proteins against the potentially harsh surrounding microenvironment [71].

In this paper, CMCA hydrogels used in combination with PA2-E12, a clonal cell line obtained from a hADSCs line, did not result to be suitable to promote cell adhesion, as a consequence of basal chemical structure hydrogels, and determined a rounded cell morphology. In literature, data have shown that the hydrogel's surface must be chemically or biologically engineered (e.g., with the addition of adhesion ligands, short fragments of bioactive molecules) to obtain good bioactivity $[72,73]$.

The presence of CMCA hydrogel in the transwell for the PA2-E12 cells cultured on tPS did not modify the osteogenic characteristics of these cells, with no interference to the osteogenic differentiation process and without toxic effects. These data obtained on the biocompatibility have shown that CMCA hydrogels had the characteristics to be modified with the addition of bioactive molecules. In fact, we have modified the characteristics of hydrogel with addition of different concentrations of $\mathrm{Sr}^{2+}$ to investigate the effects of strontium release from CMCA hydrogel on the osteodifferentiation of PA2-E12 cells. The $3 \mathrm{mM} \mathrm{Sr}^{2+}$ concentration loaded on CMCA hydrogel was able to promote the osteodifferentiation of PA2-E12 cells, as shown by increased ALP activity at 7 and 14 days compared to OM. Moreover, at 7 days the response of ALP production in CMCA enriched with $3 \mathrm{mM} \mathrm{Sr}^{2+}$ was analogous to that of the cells cultured in OM with $3 \mathrm{mM}$ $\mathrm{Sr}^{2+}$, probably due to an initial high release of $\mathrm{Sr}^{2+}$ in culture medium, able to more quickly direct the osteodifferentiation of the PA2-E12. CMCA hydrogel enriched with $3 \mathrm{mM} \mathrm{Sr}^{2+}$ was also able to promote the formation of HA deposits, as shown by increased HA activity at 14 days compared to OM. This response was similar to that obtained with the cells cultured in $\mathrm{OM}$ with $30 \mu \mathrm{M} \mathrm{Sr}^{2+}$, probably due to the similar $\mathrm{Sr}^{2+}$ concentrations present in the culture medium. In fact, at 14 days the $\mathrm{Sr}^{2+}$ concentrations accumulated in the culture medium after release from the hydrogel enriched with $3 \mathrm{mM}$ of $\mathrm{Sr}^{2+}$ was about $20 \mu \mathrm{M}$. These results are confirmed by qualitative analysis of ALP activity and of HA formation for PA2-E12 cells with light microscopy observation after staining. In fact, $3 \mathrm{mM} \mathrm{Sr}^{2+}$ loaded in CMCA and $30 \mu \mathrm{M} \mathrm{Sr}^{2+}$ directly added to $\mathrm{OM}$, the more responsive concentrations of $\mathrm{Sr}^{2+}$ resulting from the quantitative analysis, were able to increase the number of ALP+ cells and the density of HA deposits compared to control at 14 days of osteoinduction.

The higher doses (e.g., $300 \mu \mathrm{M}$ and $3 \mathrm{mM}$ ) of $\mathrm{Sr}^{2+}$ in the cells cultured on tPS seem to inhibit the formation of 


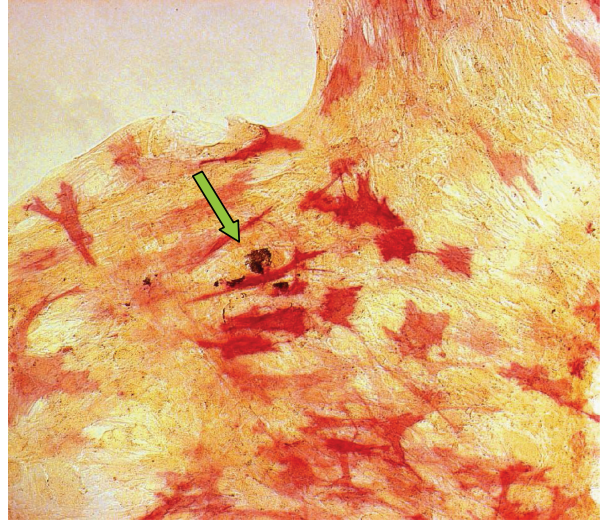

(a)

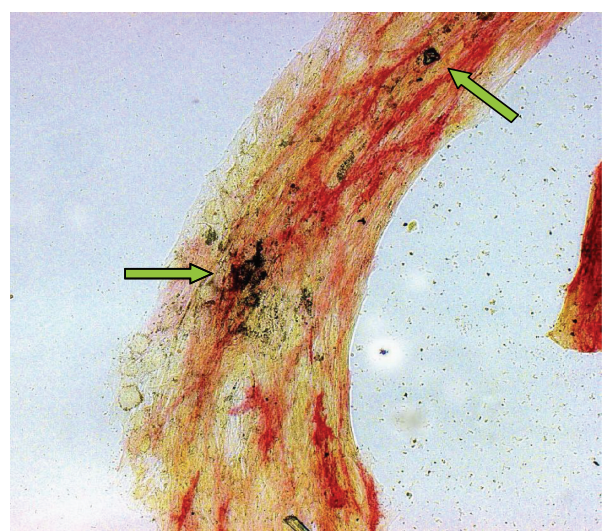

(b)

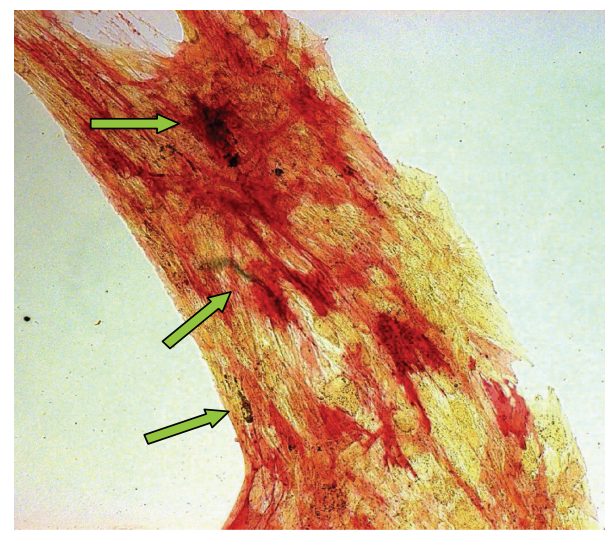

(c)

FIGURE 4: PA2-E12 cultured on tPS for 14 days in OM alone (a), in $\mathrm{OM}$ added with $30 \mu \mathrm{M} \mathrm{Sr}{ }^{2+}$ (b), and without in the presence of gelenriched with $3 \mathrm{mM} \mathrm{Sr}^{2+}$ (c). Cells fixed and stained for ALP. Observation in brightfield microscopy (10x objective): ALP+ cells intensity in red, ALP - cells in yellow, and HA deposits in black (green arrows).

HA deposits presupposing alterations of the physicochemical properties in the structure of hydroxyapatite crystal up to impede its formation [74].

In conclusion, multiple physical, chemical, and biological mechanisms are involved in tissue regeneration in vitro and in vivo using biomaterials [75]. The threedimensionality, the biocompatibility, and biodegradability of hydrogel and its chemical surface characteristics, due to addition of biofactors able to promote fundamental cell biological processes, are needed to design successful biomaterials for tissue regeneration applications. Currently, attention is focused on the creation of scaffolds with drug-delivery capacity. Scaffolds can represent biofactors' reservoirs, are released during time, and are able to promote cell growth and/or differentiation, allowing more rapid bone healing. On the basis of our results, $\mathrm{Sr}^{2+}$ ion released from CMCA hydrogel enhanced bone cell differentiation of the PA2-E12 cell line, accelerating new bone matrix formation. These data suggest that hADSCs, combined with enriched biomaterials able to release in situ agents effective in osteogenic differentiation, could represent a successful strategy to develop innovative techniques for bone tissue engineering.

\section{Conflict of Interests}

The authors declare that they have no conflict of interests.

\section{Acknowledgments}

The authors are grateful to BioSuMa (Lima Corporate S.p.a. Villanova di San Daniele del Friuli, Italy) for the supply of CMCA hydrogels. This work was supported by a grant from the Italian Ministry of Health, Program for Health Research 2007, for the project "Development of Biocompatible Hydrogels Engineered as Cell and Bioactive Factor Carriers for Improving Osseointegration of Biomedical Implants" and by Les Laboratoires Servier, Neuilly-sur-Seine, France (to M. L. Brandi).

\section{References}

[1] K. Arvidson, B. M. Abdallah, L. A. Applegate et al., "Bone regeneration and stem cells," Journal of Cellular and Molecular Medicine, vol. 15, no. 4, pp. 718-746, 2011.

[2] G. Ciapetti, L. Ambrosio, L. Savarino et al., "Osteoblast growth and function in porous poly $\varepsilon$-caprolactone matrices for bone 
repair: a preliminary study," Biomaterials, vol. 24, no. 21, pp. 3815-3824, 2003.

[3] A. S. P. Lin, T. H. Barrows, S. H. Cartmell, and R. E. Guldberg, "Microarchitectural and mechanical characterization of oriented porous polymer scaffolds," Biomaterials, vol. 24, no. 3, pp. 481-489, 2003.

[4] U. Kneser, D. J. Schaefer, E. Polykandriotis, and R. E. Horch, "Tissue engineering of bone: the reconstructive surgeon's point of view," Journal of Cellular and Molecular Medicine, vol. 10, no. 1, pp. 7-19, 2006.

[5] J. S. Temenoff and A. G. Mikos, "Injectable biodegradable materials for orthopedic tissue engineering," Biomaterials, vol. 21, no. 23, pp. 2405-2412, 2000.

[6] M. Deng, R. James, C. T. Laurencin, and S. G. Kumbar, "Nanostructured polymeric scaffolds for orthopaedic regenerative engineering," IEEE Transactions on Nanobioscience, vol. 11, no. 1, Article ID 6135509, pp. 3-14, 2012.

[7] R. Langer and J. P. Vacanti, “Tissue engineering," Science, vol. 260, no. 5110, pp. 920-926, 1993.

[8] S. Yang, K. F. Leong, Z. Du, and C. K. Chua, "The design of scaffolds for use in tissue engineering. Part I. Traditional factors," Tissue Engineering, vol. 7, no. 6, pp. 679-689, 2001.

[9] C. Weinand, I. Pomerantseva, C. M. Neville et al., "Hydrogel$\beta$-TCP scaffolds and stem cells for tissue engineering bone," Bone, vol. 38, no. 4, pp. 555-563, 2006.

[10] D. Howard, L. D. Buttery, K. M. Shakesheff, and S. J. Roberts, "Tissue engineering: strategies, stem cells and scaffolds," Journal of Anatomy, vol. 213, no. 1, pp. 66-72, 2008.

[11] T. Weigel, G. Schinkel, and A. Lendlein, "Design and preparation of polymeric scaffolds for tissue engineering," Expert Review of Medical Devices, vol. 3, no. 6, pp. 835-851, 2006.

[12] A. I. Caplan and V. M. Goldberg, "Principles of tissue engineered regeneration of skeletal tissues," Clinical Orthopaedics and Related Research, no. 367, pp. S12-S16, 1999.

[13] L. A. Solchaga, V. M. Goldberg, and A. I. Caplan, "Cartilage regeneration using principles of tissue engineering," Clinical Orthopaedics and Related Research, no. 391, pp. S161-S170, 2001.

[14] C. T. Laurencin, A. M. A. Ambrosio, M. D. Borden, and J. A. Cooper, "Tissue engineering: orthopedic applications," Annual Review of Biomedical Engineering, no. 1, pp. 19-46, 1999.

[15] J. F. Mano, R. A. Sousa, L. F. Boesel, N. M. Neves, and R. L. Reis, "Bioinert, biodegradable and injectable polymeric matrix composites for hard tissue replacement: state of the art and recent developments," Composites Science and Technology, vol. 64, no. 6, pp. 789-817, 2004.

[16] W. Suchanek and M. Yoshimura, "Processing and properties of hydroxyapatite-based biomaterials for use as hard tissue replacement implants," Journal of Materials Research, vol. 13, no. 1, pp. 94-117, 1998.

[17] H. Petite, K. Vandamme, L. Monfoulet, and D. LogeartAvramoglou, "Strategies for improving the efficacy of bioengineered bone constructs: a perspective," Osteoporosis International, vol. 22, no. 6, pp. 2017-2021, 2011.

[18] R. Langer, “Tissue engineering," Molecular Therapy, vol. 1, no. 1, pp. 12-15, 2000.

[19] M. Deng, L. S. Nair, S. P. Nukavarapu et al., "In situ porous structures: a unique polymer erosion mechanism in biodegradable dipeptide-based polyphosphazene and polyester blends producing matrices for regenerative engineering," Advanced Functional Materials, vol. 20, no. 17, pp. 2794-2806, 2010.
[20] E. L. Chaikof, H. Matthew, J. Kohn, A. G. Mikos, G. D. Prestwich, and C. M. Yip, "Biomaterials and scaffolds in reparative medicine," Annals of the New York Academy of Sciences, vol. 961, pp. 96-105, 2002.

[21] A. J. Friedenstein, K. V. Petrakova, A. I. Kurolesova, and G. P. Frolova, "Heterotopic of bone marrow. Analysis of precursor cells for osteogenic and hematopoietic tissues," Transplantation, vol. 6, no. 2, pp. 230-247, 1968.

[22] A. J. Friedenstein, I. I. Piatetzky-Shapiro, and K. V. Petrakova, "Osteogenesis in transplants of bone marrow cells," Journal of Embryology and Experimental Morphology, vol. 16, no. 3, pp. 381-390, 1966.

[23] M. F. Pittenger, A. M. Mackay, S. C. Beck et al., "Multilineage potential of adult human mesenchymal stem cells," Science, vol. 284, no. 5411, pp. 143-147, 1999.

[24] P. A. Zuk, M. Zhu, P. Ashjian et al., "Human adipose tissue is a source of multipotent stem cells," Molecular Biology of the Cell, vol. 13, no. 12, pp. 4279-4295, 2002.

[25] O. K. Lee, T. K. Kuo, W. M. Chen, K. D. Lee, S. L. Hsieh, and T. H. Chen, "Isolation of multipotent mesenchymal stem cells from umbilical cord blood," Blood, vol. 103, no. 5, pp. 16691675, 2004.

[26] P. De Coppi, G. Bartsch, M. M. Siddiqui et al., "Isolation of amniotic stem cell lines with potential for therapy," Nature Biotechnology, vol. 25, no. 1, pp. 100-106, 2007.

[27] S. Gronthos, J. Brahim, W. Li et al., "Stem cell properties of human dental pulp stem cells," Journal of Dental Research, vol. 81, no. 8, pp. 531-535, 2002.

[28] P. Seale, A. Asakura, and M. A. Rudnicki, "The potential of muscle stem cells," Developmental Cell, vol. 1, no. 3, pp. 333342, 2001.

[29] R. Quarto, M. Mastrogiacomo, R. Cancedda et al., "Repair of large bone defects with the use of autologous bone marrow stromal cells," New England Journal of Medicine, vol. 344, no. 5, pp. 385-386, 2001.

[30] M. Reyes, A. Dudek, B. Jahagirdar, L. Koodie, P. H. Marker, and C. M. Verfaillie, "Origin of endothelial progenitors in human postnatal bone marrow," Journal of Clinical Investigation, vol. 109, no. 3, pp. 337-346, 2002.

[31] S. Makino, K. Fukuda, S. Miyoshi et al., "Cardiomyocytes can be generated from marrow stromal cells in vitro," Journal of Clinical Investigation, vol. 103, no. 5, pp. 697-705, 1999.

[32] W. Deng, M. Obrocka, I. Fischer, and D. J. Prockop, "In vitro differentiation of human marrow stromal cells into early progenitors of neural cells by conditions that increase intracellular cyclic AMP," Biochemical and Biophysical Research Communications, vol. 282, no. 1, pp. 148-152, 2001.

[33] R. E. Schwartz, M. Reyes, L. Koodie et al., "Multipotential adult rogenitor cells from bone marrow differentiation into functional hepatocyte-like cells," The Journal of Clinical Investigation, vol. 109, pp. 1291-1302, 2002.

[34] J. F. Connolly, "Injectable bone marrow preparations to stimulate osteogenic repair," Clinical Orthopaedics and Related Research, no. 313, pp. 8-18, 1995.

[35] J. J. Tiedeman, J. F. Connolly, B. S. Strates, and L. Lippiello, "Treatment of nonunion by percutaneous injection of bone marrow and demineralized bone matrix: an experimental study in dogs," Clinical Orthopaedics and Related Research, no. 268, pp. 294-302, 1991.

[36] Y. Zhao, H. Lin, J. Zhang et al., "Crosslinked threedimensional demineralized bone matrix for the adiposederived stromal cell proliferation and differentiation," Tissue Engineering A, vol. 15, no. 1, pp. 13-21, 2009. 
[37] L. Hong, A. Colpan, I. A. Peptan, J. Daw, A. George, and C. A. Evans, "17- $\beta$ estradiol enhances osteogenic and adipogenic differentiation of human adipose-derived stromal cells," Tissue Engineering, vol. 13, no. 6, pp. 1197-1203, 2007.

[38] I. Tognarini, S. Sorace, R. Zonefrati et al., "In vitro differentiation of human mesenchymal stem cells on Ti6Al4V surfaces," Biomaterials, vol. 29, no. 7, pp. 809-824, 2008.

[39] J. L. Drury and D. J. Mooney, "Hydrogels for tissue engineering: scaffold design variables and applications," Biomaterials, vol. 24, no. 24, pp. 4337-4351, 2003.

[40] A. S. Hoffman, "Hydrogels for biomedical applications," Annals of the New York Academy of Sciences, vol. 944, pp. 6273, 2001.

[41] D. Lickorish, J. A. M. Ramshaw, J. A. Werkmeister, V. Glattauer, and C. R. Howlett, "Collagen-hydroxyapatite composite prepared by biomimetic process," Journal of Biomedical Materials Research A, vol. 68, no. 1, pp. 19-27, 2004.

[42] T. J. Webster, C. Ergun, R. H. Doremus, R. W. Siegel, and R. Bizios, "Specific proteins mediate enhanced osteoblast adhesion on nanophase ceramics," Journal of Biomedical Materials Research, vol. 51, no. 3, pp. 475-483, 2000.

[43] T. J. Webster, R. W. Siegel, and R. Bizios, "Osteoblast adhesion on nanophase ceramics," Biomaterials, vol. 20, no. 13, pp. 1221-1227, 1999.

[44] J. A. Burdick and K. S. Anseth, "Photoencapsulation of osteoblasts in injectable RGD-modified PEG hydrogels for bone tissue engineering," Biomaterials, vol. 23, no. 22, pp. 4315-4323, 2002.

[45] C. G. Williams, T. K. Kim, A. Taboas, A. Malik, P. Manson, and J. Elisseeff, "In vitro chondrogenesis of bone marrow-derived mesenchymal stem cells in a photopolymerizing hydrogel," Tissue Engineering, vol. 9, no. 4, pp. 679-688, 2003.

[46] A. M. Carossino, R. Recenti, R. Carossino et al., "Methodological models for in vitro amplification and maintenance of human articular chondrocytes from elderly patients," Biogerontology, vol. 8, no. 5, pp. 483-498, 2007.

[47] S. J. Bryant and K. S. Anseth, "Controlling the spatial distribution of ECM components in degradable PEG hydrogels for tissue engineering cartilage," Journal of Biomedical Materials Research A, vol. 64, no. 1, pp. 70-79, 2003.

[48] G. Leone, M. Fini, P. Torricelli, R. Giardino, and R. Barbucci, "An amidated carboxymethylcellulose hydrogel for cartilage regeneration," Journal of Materials Science, vol. 19, no. 8, pp. 2873-2880, 2008.

[49] M. Ulrich-Vinther, M. D. Maloney, E. M. Schwarz, R. Rosier, and R. J. O'Keefe, "Articular cartilage biology," The Journal of the American Academy of Orthopaedic Surgeons, vol. 11, no. 6, pp. 421-430, 2003.

[50] Z. Hamidouche, O. Fromigué, J. Ringe et al., "Priming integrin $\alpha 5$ promotes human mesenchymal stromal cell osteoblast differentiation and osteogenesis," Proceedings of the National Academy of Sciences of the United States of America, vol. 106, no. 44, pp. 18587-18591, 2009.

[51] H. W. Kim, J. C. Knowles, and H. E. Kim, "Hydroxyapatite/poly( $\varepsilon$-caprolactone) composite coatings on hydroxyapatite porous bone scaffold for drug delivery," Biomaterials, vol. 25, no. 7-8, pp. 1279-1287, 2004.

[52] L. Di Silvio and W. Bonfield, "Biodegradable drug delivery system for the treatment of bone infection and repair," Journal of Materials Science, vol. 10, no. 10-11, pp. 653-658, 1999.

[53] H. Shin, S. Jo, and A. G. Mikos, "Biomimetic materials for tissue engineering," Biomaterials, vol. 24, no. 24, pp. 43534364, 2003.
[54] C. Csaki, P. R. A. Schneider, and M. Shakibaei, "Mesenchymal stem cells as a potential pool for cartilage tissue engineering," Annals of Anatomy, vol. 190, no. 5, pp. 395-412, 2008.

[55] T. Garg, O. Singh, S. Arora, and R. S. R. Murthy, "Scaffold: a novel carrier for cell and drug delivery," Critical Reviews in Therapeutic Drug Carrier Systems, vol. 29, no. 1, pp. 1-63, 2012.

[56] P. J. Meunier, C. Roux, E. Seeman et al., "The effects of strontium ranelate on the risk of vertebral fracture in women with postmenopausal osteoporosis," New England Journal of Medicine, vol. 350, no. 5, pp. 459-468, 2004.

[57] J. Y. Reginster, E. Seeman, M. C. De Vernejoul et al., "Strontium ranelate reduces the risk of nonvertebral fractures in postmenopausal women with osteoporosis: Treatment of Peripheral Osteoporosis (TROPOS) study," Journal of Clinical Endocrinology and Metabolism, vol. 90, no. 5, pp. 2816-2822, 2005.

[58] P. J. Marie, "Strontium ranelate: a novel mode of action optimizing bone formation and resorption," Osteoporosis International, vol. 16, no. 1, pp. S7-S10, 2005.

[59] P. J. Marie, "Strontium ranelate: a dual mode of action rebalancing bone turnover in favour of bone formation," Current Opinion in Rheumatology, vol. 18, no. 1, pp. S11-S15, 2006.

[60] E. Bonnelye, A. Chabadel, F. Saltel, and P. Jurdic, "Dual effect of strontium ranelate: stimulation of osteoblast differentiation and inhibition of osteoclast formation and resorption in vitro," Bone, vol. 42, no. 1, pp. 129-138, 2008.

[61] P. J. Marie, D. Felsenberg, and M. L. Brandi, "How strontium ranelate, via opposite effects on bone resorption and formation, prevents Osteoporosis," Osteoporosis International, vol. 22, no. 6, pp. 1659-1667, 2011.

[62] K. Qiu, X. J. Zhao, C. X. Wan, C. S. Zhao, and Y. W. Chen, "Effect of strontium ions on the growth of ROS17/2.8 cells on porous calcium polyphosphate scaffolds," Biomaterials, vol. 27, no. 8, pp. 1277-1286, 2006.

[63] W. Song, Q. Wang, C. Wan et al., "A novel alkali metals/strontium co-substituted calcium polyphosphate scaffolds in bone tissue engineering," Journal of Biomedical Materials Research B, vol. 98, no. 2, pp. 255-262, 2011.

[64] F. Liu, X. Zhang, X. Yu, Y. Xu, T. Feng, and D. Ren, "In vitro study in stimulating the secretion of angiogenic growth factors of strontium-doped calcium polyphosphate for bone tissue engineering," Journal of Materials Science, vol. 22, no. 3, pp. 683-692, 2011.

[65] R. Barbucci, G. Leone, M. Monici, D. Pantalone, M. Fini, and R. Giardino, "The effect of amidic moieties on polysaccharides: evaluation of the physicochemical and biological properties of amidic carboxymethylcellulose (CMCA) in the form of linear polymer and hydrogel," Journal of Materials Chemistry, vol. 15, no. 22, pp. 2234-2241, 2005.

[66] D. Beauchemin, "Inductively coupled plasma mass spectrometry," Analytical Chemistry, vol. 78, no. 12, pp. 4111-4135, 2006.

[67] J. A. Hubbell, "Bioactive biomaterials," Current Opinion in Biotechnology, vol. 10, no. 2, pp. 123-129, 1999.

[68] K. E. Healy, "Molecular engineering of materials for bioreactivity," Current Opinion in Solid State and Materials Science, vol. 4, no. 4, pp. 381-387, 1999.

[69] S. E. Sakiyama-Elbert and J. A. Hubbell, "Functional biomaterials: design of novel biomaterials," Annual Review of Materials Science, vol. 31, pp. 183-201, 2001.

[70] M. J. Humphries, S. K. Akiyama, and A. Komoriya, "Identification of an alternatively spliced site in human plasma 
fibronectin that mediates cell type-specific adhesion," Journal of Cell Biology, vol. 103, no. 6, pp. 2637-2647, 1986.

[71] T. Garg, O. Singh, S. Arora, and R. S. R. Murthy, "Scaffold: a novel carrier for cell and drug delivery," Critical Reviews in Therapeutic Drug Carrier Systems, vol. 29, no. 1, pp. 1-63, 2012.

[72] J. A. Rowley, G. Madlambayan, and D. J. Mooney, "Alginate hydrogels as synthetic extracellular matrix materials," Biomaterials, vol. 20, no. 1, pp. 45-53, 1999.

[73] M. P. Lutolf, F. E. Weber, H. G. Schmoekel et al., "Repair of bone defects using synthetic mimetics of collagenous extracellular matrices," Nature Biotechnology, vol. 21, no. 5, pp. 513-518, 2003.

[74] S. C. Verberckmoes, G. J. Behets, L. Oste et al., "Effects of strontium on the physicochemical characteristics of hydroxyapatite," Calcified Tissue International, vol. 75, no. 5, pp. 405415, 2004.

[75] M. P. Lutolf and J. A. Hubbell, "Synthetic biomaterials as instructive extracellular microenvironments for morphogenesis in tissue engineering," Nature Biotechnology, vol. 23, no. 1, pp. 47-55, 2005. 

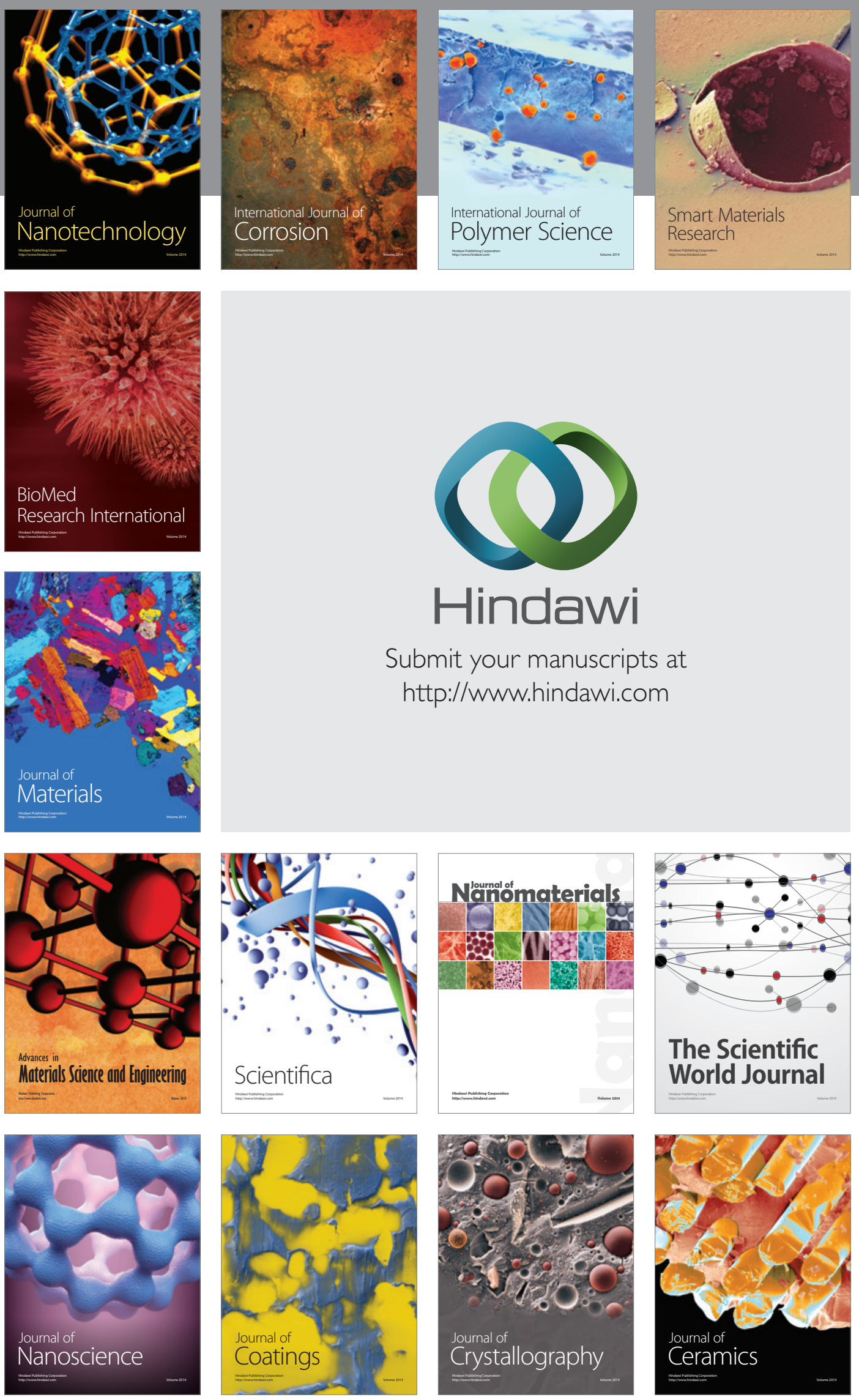

The Scientific World Journal

Submit your manuscripts at

http://www.hindawi.com

\section{World Journal}

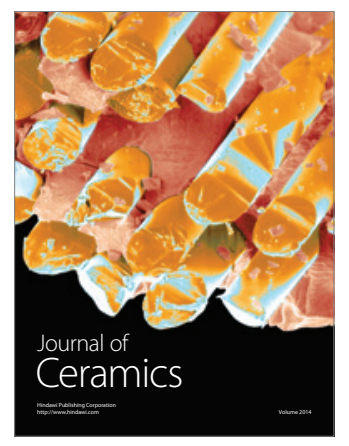

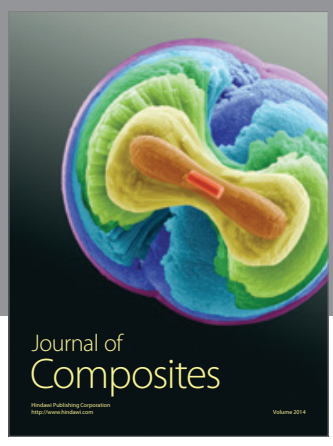
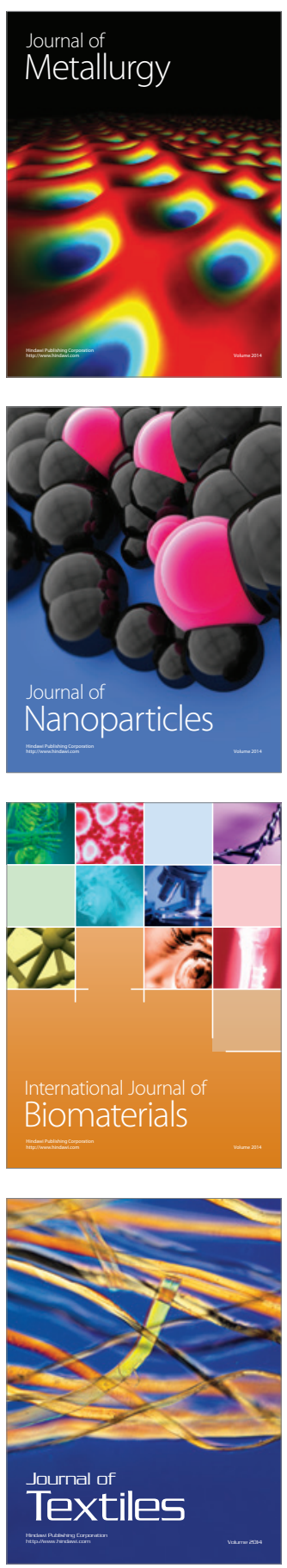